\title{
Canadian Author Study: Pre-service Teachers Engage in Assignments to Promote Awareness of Canadian Young Adult Literature
}

\author{
Ruth McQuirter Scott \\ Brock University
}

\begin{abstract}
This article describes an initiative designed to familiarize pre-service teachers with a wide range of Canadian authors of young adult literature. Teacher candidates work in small groups to study at least three novels by the same author. Each group presents its findings in a creative manner to the class. This background material is then used to prepare a language unit that focuses on one of the following: the author, common themes, or interdisciplinary connections.
\end{abstract}

Canadian children's literature has shown remarkable growth in the past 30 years. Courtland (2000) attributes this, in part, to the surge in nationalism in Canada's centennial year, 1967, as well as to the expansion by Canadian publishers to the international market. The Canadian Society of Children's Authors, Illustrators and Performers (CANSCAIP) currently lists 383 members, and an event in Ontario to mark the twenty-fifth birthday of CANSCAIP featured 25 local authors who presented 31 children's books published in 2003.

Courtland points to the important role played by Canadian children's literature:

Canadian children's literature, then, speaks to Canadians in particular ways. While the themes may indeed be universal and hold appeal for international readers, just as outstanding works from other countries may delight and move us, authorship, content, settings, and characters in Canadian children's literature evoke deeply personal connections in us. (p.21)

Ruth McQuirter Scott, Ed.D., is an Associate Professor in the Faculty of Education, Brock University, St. Catharines, Ontario. She is the 2004 recipient of the Faculty of Education Teaching Excellence Award. 
It would seem reasonable to expect, then, that Canadian children's literature would be featured prominently in Canadian classrooms and that Canadian authors and their books would be familiar to most students. Elliott's ongoing study of children and the media, however, is yielding results contrary to these predictions. In the first year of the study, children in grades one, four, and six were asked to name their favorite book. No Canadian text was listed in the overall selection of the top 21 books. (http://childmedia.ed.brocku.ca/ reading1.php).

As an instructor of language in a pre-service program at a Canadian faculty of education, I have found that few of my students have taken a children's literature course in their undergraduate years, and fewer still have an academic background in Canadian children's literature. When questioned about their knowledge of Canadian children's writers and their texts, most students call upon childhood memories and recall books such as Anne of Green Gables.

Rarely does a student identify a Canadian children's novel published in the past decade.

Nodelman and Reimer (2000) found that even when their undergraduate students sought out Canadian children's literature in bookstores, it was a difficult task. While some bookstores placed Canadian children's books in special sections and some libraries put maple-leaf stickers on book spines, many did not. In such cases, students found that Canadian books were indistinguishable in appearance from books produced in the United States or Britain. The problem of lack of distinctiveness extended beyond the external appearance to the content of the books. Few students were able to identify which of the books they had read as children or adults were actually Canadian. Many were surprised to hear, for example, that Robert Munsch or Gordon Korman are Canadian writers.

The purpose of this paper is to describe how a novel study unit, used in a language arts course in an Ontario faculty of education, helped pre-service students increase their awareness of Canadian authors of young adult children's literature.

\section{Students}

The 120 students enrolled in four sections of their junior/intermediate (grades 48) language arts course met once a week during their pre-service year. This compulsory course included students from a variety of academic backgrounds and was not restricted to those with a major in English literature. There was a strong likelihood that all students would be required to teach language arts in at least one of their three practicum placements. If hired the following year to 
teach in a junior division classroom (grades 4-6), most would be expected to teach language arts as part of a core teaching assignment. Those students for whom language arts was an identified teachable subject in their preservice year would have at least one full practicum placement in a language classroom in grade 7 or 8 and an increased likelihood of being hired to teach language arts the following year.

\section{Course Description}

The Junior/Intermediate division language arts course consists of 20 sessions, each lasting two and one-half hours. A colleague and I share responsibility for four sections of 30 students. The classes meet in a classroom setting that is structured to include a balance between lecturer input and practical applications through small group and individual activities.

The course philosophy and content are consistent with expectations set by the Ontario College of Teachers in Foundations of Professional Practice (2000) and the Ontario Curriculum: Grades 1-8 Language (1997). Assignments are divided into three general categories, with the teacher as reader; writer; researcher and planner. This paper describes assignments in two of the three areas: the teacher as reader and the teacher as researcher and planner.

\section{Canadian Young Adult Literature Assignments}

\section{The Teacher as Reader: Canadian Author Study}

The Canadian Young Adult Literature assignment is divided into two parts. The first focuses on the reading of Canadian novels written for and about children approximately 10 to 14 years of age. A pre-selected list of authors and their works is prepared ahead of time by the instructors, although other choices are allowed if requested. To be included on the list, an author must have written at least three novels for this age group and these works must be currently available. Selections represent various genres such as realistic fiction, historical fiction, and modern fantasy. A listing of authors is found in Figure 1. 
Figure 1

List of Canadian authors of young adult literature

\section{Canadian Authors of Young Adult Literature}

$\begin{array}{ll}\text { Linda Bailey } & \text { Kevin Major } \\ \text { William Bell } & \text { Sylvia McNicholl } \\ \text { Karleen Bradford } & \text { Lucy Maud Montgomery } \\ \text { Brian Doyle } & \text { Farley Mowat } \\ \text { Deborah Ellis } & \text { Kit Pearson } \\ \text { Barbara Greenwood } & \text { Gisela Tobien Sherman } \\ \text { James Houston } & \text { Sharon Siamon } \\ \text { Monica Hughes } & \text { Cora Taylor } \\ \text { Gordon Korman } & \text { Ian Wallace } \\ \text { Paul Kropp } & \text { Eric Walters } \\ \text { Jean Little } & \text { Eric Wilson } \\ \text { Janet Lunn } & \text { Tim Wynne-Jones } \\ \text { Roy MacGregor } & \end{array}$

Pre-service candidates work in small groups of three or four. Each group chooses one author to study from the list. Each student selects one novel to read, so that at least three novels will be studied for each writer. After reading the novel, each student prepares a one or two page written review that is supplied to the whole class. This written component must contain the following features:

- a synopsis of the plot in which key elements of the novel are identified

- a personal response to the novel

- an author profile containing a brief biographical sketch and relevant web sites

- comments on the writing form or genre and literary elements utilized by the author

- grade appropriate themes and topics emerging from the novel

- links with Ontario Ministry of Education language expectations

- assessment strategies tied to the expectations

- suggestions for reading responses related to the novel

- potential cross-curricular links 
The group representing each author is assigned a presentation date in which they are allotted 20 minutes to highlight their findings. They are encouraged to present their author and his or her novels in a creative way, in addition to the formal written reviews described above. Students have used a variety of formats to get away from the traditional "book report" presentation. These have included skits and dramatizations from the novels, mock interviews with the author or characters, actual videotaped interviews with the author, game show formats, infomercials, memorabilia boxes, award shows, and puppet shows. One group did a take-off on the movie "Blair Witch Project" when presenting the works of Jean Little. They drove to Jean Little's hometown, Guelph, Ontario, and used a videocamera to interview shopkeepers about the author's whereabouts. The tape eventually led to a scary night-time scene in the woods, a spoof that had the class doubled up with laughter.

The author presentations are evaluated by the instructor and comprise $20 \%$ of the final grade for the course.

By the end of the presentations, each class of 30 has been introduced to approximately 10 Canadian children's authors and has 30 separate book reviews of novels for young adults. Students report after graduating that these reviews are valuable the following year when they have their own classrooms and are asked to make decisions for book purchases.

\section{The Teacher as Researcher and Planner: Language Unit}

In the second term of the course, each group is required to create a unit plan based on the novels read. An emphasis is placed on intertextual links, showing relationships among the novels in one of the following ways:

- a novel study exploring the text set from the perspective of elements of fiction such as plot, characterization, and setting

- $\quad$ an author study comparing the writer's techniques across the novels studied

- a thematic study identifying a key theme in the novels

- a cross-curricular study linking components of the novels with other content areas such as social studies, science, or the arts.

The unit plans are based on a backward design model (Wiggins \& McTighe, 2001), beginning with the description of a culminating activity or demonstration task, and including appropriate curriculum expectations, lesson plans, assessment measures, and references. Each unit is mounted on a three-panel 
display board and is presented as a poster session during a class set aside for this purpose. Students briefly describe their unit, and then have an opportunity to circulate and view the work of other groups. The plans are then on display in the campus library for other pre-service students to view.

This assignment is evaluated by the instructor and counts $20 \%$ toward the final grade for the course.

\section{Conclusion}

My colleague and I have found the Canadian author assignments to be beneficial in enhancing our students' knowledge of Canadian young adult literature. By the end of the course, each pre-service student is in possession of 30 novel overviews linking the works to appropriate curriculum expectations, teaching strategies, and cross-curricular links. They have modeled creative ways of presenting authors, and can offer these alternatives to their future classes in place of the traditional book report format.

In both the author review and unit plan, students work collaboratively, a skill increasingly important in today's schools. Because the unit plan incorporates most aspects of our overall language course, including varied teaching strategies, identification of expectations, assessment and evaluation measures, and program modifications, it represents the culminating activity for our language course.

\section{References}

Courtland, M. (2000). Young adolescent literature in Canada. In M. Courtland \& T. Gambell (Eds.), Young adolescents meet literature: Intersections for learning (pp. 19-45). Vancouver: Pacific Educational Press.

Elliott, A. (2004). Children's stories as cultural mirrors. Retrieved January 12, 2004, from http://childmedia.ed.brocku.ca/reading1.php.

Nodelman, P. \& Reimer, M. (2000). Teaching Canadian children's literature: Learning to know more. Canadian Children's Literature, 26(2): 15-35.

The foundations of professional practice. (2000). Toronto, ON: The Ontario College of Teachers.

The Ontario curriculum: Grades 1-8 language. (1997). Toronto, ON: Ministry of Education.

Wiggins, G. \& McTighe, J. (2001). Understanding by design. Upper Saddle River, N.J.:Merrill/Prentice Hall. 